\title{
Embryotoxicity estimation of commonly used compounds with embryonic stem cell test
}

\author{
HUI LIU ${ }^{1}$, CAIPING REN ${ }^{1}$, WEIDONG LIU ${ }^{1}$, XINGJUN JIANG ${ }^{2}$, LEI WANG ${ }^{1}$, \\ BIN ZHU $^{1}$, WEI JIA ${ }^{1}$, JIANXING LIN ${ }^{1}$, JUN TAN ${ }^{2}$ and XIUYING LIU ${ }^{3}$ \\ ${ }^{1}$ Cancer Research Institute, Collaborative Innovation Center for Cancer Medicine, Key Laboratory for Carcinogenesis \\ of Chinese Ministry of Health, School of Basic Medical Science, Central South University, Changsha, Hunan 410078; \\ ${ }^{2}$ Department of Neurosurgery, Xiangya Hospital, Central South University, Changsha, Hunan 410008; \\ ${ }^{3}$ Hunan Provincial Center for Disease Control and Prevention, Changsha, Hunan 410005, P.R. China
}

Received February 27, 2016; Accepted Febraury 27, 2017

DOI: $10.3892 / \mathrm{mmr} .2017 .6552$

\begin{abstract}
The embryonic stem cell test (EST), an alternative model to animal studies, is a reliable and scientifically validated in vitro system for testing embryotoxicity. In contrast to most in vivo animal tests, two permanent cell lines, murine fibroblasts (BALB/c-3T3 cells) and murine embryonic stem cells (mES-D3 cells), are used in EST instead of animals in standard tests of toxicity. The embryotoxic potential of compounds (non, weak or strong embryotoxicity) may be obtained with a biostatistics-based prediction model and calculated from three different experimental endpoint values: The potency to inhibit growth of i) BALB/c-3T3 cells and ii) mES-D3 cells $\left(\mathrm{IC}_{50} 3 \mathrm{~T} 3\right.$ and $\left.\mathrm{IC}_{50} \mathrm{ES}\right)$ as presented using a cell cytotoxicity assay, and iii) the potency to inhibit differentiation of mES-D3 cells into contracting cardiomyocytes $\left(\mathrm{ID}_{50} \mathrm{D} 3\right.$ ) as demonstrated in a mES-D3 cell differentiation assay. In the present study, a model of EST with mES-D3 cells and BALB/c-3T3 cells was established, according to the standard EST system of the EU Center for the Validation of Alternative Methods, and verified it with 5-fluorouracil (strong embryotoxicity) as a positive control and penicillin $\mathrm{G}$ (non-embryotoxic) as a negative control. In addition, the authors further assessed the embryotoxicity of four compounds (eugenol, carnosic acid, procyanidin and dioctyl phthalate) with this model. The embryotoxic potentials of the four compounds were successfully classified by the EST system. Eugenol exhibited strong embryotoxicity, carnosic
\end{abstract}

Correspondence to: Dr Caiping Ren, Cancer Research Institute, Collaborative Innovation Center for Cancer Medicine, Key Laboratory for Carcinogenesis of Chinese Ministry of Health, School of Basic Medical Science, Central South University, 110 Xiangya Road, Changsha, Hunan 410078, P.R. China

E-mail: rencaiping@csu.edu.cn

Dr Xiuying Liu, Hunan Provincial Center for Disease Control and Prevention, 450 Furong Road, Changsha, Hunan 410005, P.R. China E-mail: 820363269@qq.com

Key words: embryonic stem cell test, embryotoxicity, embryonic stem cell, compounds acid and dioctyl phthalate exhibited weak embryotoxicity, while procyanidin exhibited non-embryotoxicity.

\section{Introduction}

The embryonic stem cell test (EST), which was developed by Scholz et al (1), was designed for the in vitro embryotoxicity testing of drugs and other chemicals (2-6). It uses two permanent murine cell lines: The murine embryonic stem cell line (mES-D3 cells, applied to analyze the effects of compounds on the developing embryo) and the differentiated fibroblast cell line (BALB/c-3T3 cells, applied to analyze the effects of compounds on adult tissues and organs). In vitro, murine embryonic stem (mES) cells may be cultured by the hanging drop-suspension-adherence method to form embryoid bodies (EBs) in the absence of anti-differentiation agents (e.g., embryonic fibroblasts and leukemia inhibitory factor,LIF). These EBs, when subsequently seeded in dishes, can spontaneously differentiate to form contracting cardiomyocytes (7-9). The process of differentiation of mES cells into cells of all three germ layers within EBs, as well as the expression of tissue specific proteins, closely resemble the in vivo processes in developing embryos $(10,11)$. Therefore treating mES cells during in vitro differentiation with the compound of interest may be very useful to obviate unwanted negative effects on embryonic development. The myosin heavy chain (MHC) gene is characteristic of atrial and ventricular cells during early embryonic heart development, and can serve as a marker gene for cardiac development during mES cell differentiation (12). The established EST takes advantage of these properties of $\mathrm{mES}$ cells by assessing the degree of inhibition that the test compounds causes in their differentiation processes (13-15).

For classification of the embryotoxic potential of test compounds, three different endpoints could be detected following treatment with the compounds: Cytotoxicity analysis of i) mES cells and ii) 3T3 cells (the concentration of the test compounds resulting in a 50\% decrease in the viability of $\mathrm{mES}$ cells and $3 \mathrm{~T} 3$ cells, $\mathrm{IC}_{50} \mathrm{ES} / \mathrm{IC}_{50} 3 \mathrm{~T} 3$ ) and iii) the inhibition of differentiation of mES cells (the concentration of the test compounds that causes a 50\% inhibition of the differentiation of $\mathrm{mES}$ cells into contracting cardiomyocytes, $\left.\mathrm{ID}_{50} \mathrm{D} 3\right)(16-18)$. 
When the $\mathrm{IC}_{50}$ and $\mathrm{ID}_{50}$ values are applied to a biostatistical prediction model (PM) developed by the Center for Documentation and Evaluation of Alternative Methods to Animal Experiments and based on linear discriminant functions, the test compounds can be classified into three different classes according to in vivo embryotoxic potencies: Strong, weak or non-embryotoxicity (19).

The present study was conducted in two consecutive stages:

Phase I: According to the standard EST protocol of the European Centre for the Validation of Alternative Methods (ECVAM), an EST model was established, and two chemicals with known in vivo embryotoxic potential were tested: 5-fluorouracil (strong embryotoxicity) and penicillin G (non-embryotoxic). This was conducted in order to evaluate the feasibility of the model $(2,20)$.

Phase II: The embryotoxicity of four compounds was assessed (eugenol, carnosic acid, procyanidin and dioctyl phthalate) with the EST model.

Eugenol is a biologically active phenolic component of Syzigium aromaticum (cloves). It is commonly used in perfumes, flavorings, essential oils and in medicine, due to its various biological properties such as antifungal properties and antioxidation (21-23). Carnosic acid is a phenolic diterpene compound present in considerable quantities in sage and rosemary $(24,25)$. It is increasingly used in food and cosmetic production, as well as in medicine (26-30). Procyanidin is polyphenolic bioactive compound that can be identified in high concentrations in many foods, including grapes, apples and vegetables $(31,32)$. It is also commonly used in drugs, cosmetics and foods $(33,34)$. Dioctyl phthalate, also known as diethylhexyl phthalate, is frequently used as plasticizers in the manufacture of polyvinyl chloride, which is widely used for the production of bags, storage containers and wall coverings, as well as use in medical devices (35-37). In conclusion, these four compounds possess a wide spectrum of applications, and they appear in a wide range of consumer products, as well as in medical applications. People are exposed daily to these compounds through ingestion, inhalation and dermal contact $(21,29,33,38)$. The inclusion of these compounds in personal care or consumer products used by pregnant women should be particularly noted because of the vulnerability of this population; it is crucial to investigate the embryotoxic potential of these compounds.

\section{Materials and methods}

Cell culture. mES-D3 cells (CRL1934; ATCC, Manassas, VA, USA) and BALB/c 3T3 cells (CCL-163; ATCC) were cultured at $37^{\circ} \mathrm{C}$ in a $5 \% \mathrm{CO}_{2}$ atmosphere. mES cells were routinely cultured on mouse embryonic fibroblast feeder (0303-200; Innovative Cellular Therapeutics, Co., Ltd., Shanghai, China) in the presence of leukemia inhibitory factor (LIF; PMC9484; 1,000 U/ml, Gibco; Thermo Fisher Scientific, Inc., Waltham, MA, USA) to maintain their undifferentiated status and were passaged every second day. mES cell medium consisted of Dulbecco's modified Eagle's medium (DMEM) supplemented with 10\% FBS, 2 mM GlutaMAX-I Supplement, $1 \%$ non-essential amino acids (all Gibco; Thermo Fisher Scientific, Inc.), $0.1 \% \beta$-mercaptoethanol (Merck KGaA,
Darmstadt, Germany), $50 \mathrm{U} / \mathrm{ml}$ penicillin and $50 \mu \mathrm{g} / \mathrm{ml}$ streptomycin (Sigma-Aldrich; Merck KGaA). Maintenance of BALB/c 3T3 cells used products from Gibco; Thermo Fisher Scientific, Inc., unless otherwise stated. The cells were maintained in DMEM containing 10\% FBS, 4 mM GlutaMAX-I Supplement, $50 \mathrm{U} / \mathrm{ml}$ penicillin $\mathrm{G}$ and $50 \mu \mathrm{g} / \mathrm{ml}$ streptomycin (Sigma-Aldrich; Merck MGaA).

Tested compounds. 5-fluorouracil (CAS no. 51-21-8) and penicillin G (CAS no. 69-57-8), purchased from Sigma-Aldrich; Merck KGaA, were dissolved in 1xPBS or DMEM. As for Phase II chemicals, eugenol (CAS no. 97-53-0) was purchased from Alfa Aesar; Thermo Fisher Scientific, Inc. Carnosic acid (CAS no. 3650-09-7) and procyanidin (CAS no. 4852-22-6) were purchased from Nanjing Zelang Medical Technology Co., Ltd. (Nanjing, China) and dioctyl phthalate (CAS no. 117-81-7) was purchased from Sigma-Aldrich; Merck KGaA. Eugenol, carnosic acid and dioctyl phthalate were solved in $<0.5 \%$ ethanol. Procyanidin was dissolved in DMEM.

Assessment of cytotoxicity. The cytotoxic effects of selected test compounds on $3 \mathrm{~T} 3$ cells and mES-D3 cells were determined with MTT cytotoxicity assay (1). A total of 500 cells in $50 \mu \mathrm{l}$ routine culture medium without LIF were seeded into each well of a 96 well plate (density, $1 \times 10^{4}$ cells $\left./ \mathrm{ml}\right)$. Following $2 \mathrm{~h}$ incubation at $37^{\circ} \mathrm{C}$ in $5 \% \mathrm{CO}_{2}$, culture medium $(150 \mu \mathrm{l})$, in the presence of the test compound at a range of concentrations, were added into each well except for those for the solvent control and positive control. In Phase I, eight concentrations were set for 5-fluorouracil in 1:10 dilutions from $1 \mathrm{mg} / \mathrm{ml}$ and for penicillin G from $10 \mathrm{mg} / \mathrm{ml}$. In Phase II, 5-fluorouracil served as a positive control and the appropriate concentration was set as $0.08 \mu \mathrm{g} / \mathrm{ml}$ for ES cells and $0.25 \mu \mathrm{g} / \mathrm{ml}$ for 3T3 cells. A series of seven concentrations was set for each compound in 1:10 dilutions, from $1 \mathrm{mg} / \mathrm{ml}$. The test substance and the positive control were tested in six independent experiments. The medium was replaced on day 3 and 5 of culture with new medium containing the appropriate concentration of the test chemical. The viability of the cells was determined using an MTT assay. Following 10 days of culture, the medium was replaced with $0.5 \mathrm{mg} / \mathrm{ml}$ MTT, and incubated at $37^{\circ} \mathrm{C}$ in $5 \% \mathrm{CO}_{2}$ atmosphere for $2 \mathrm{~h}$. Subsequently, MTT medium was removed from the cells. Formazan was extracted from the cells with $100 \mu 1$ dimethyl sulfoxide (DMSO, Sigma-Aldrich; Merck KGaA) per well. Following agitating the plates on a shaking incubator with a rotational radius of $10 \mathrm{~cm}$ at $200 \mathrm{rpm}$ for $15 \mathrm{~min}$, the optical density (OD) value of each well was measured at a wavelength of $570 \mathrm{~nm}$ using $630 \mathrm{~nm}$ as the reference wavelength in a PARADIGM Detection Platform (Beckman Coulter Inc., Brea, CA, USA), performed according to manufacturer's protocols. The concentration inhibiting 50\% viability of ES cells $\left(\mathrm{IC}_{50} \mathrm{ES}\right)$ or $3 \mathrm{~T} 3$ fibroblasts $\left(\mathrm{IC}_{50} 3 \mathrm{~T} 3\right)$ compared with time-matched solvent treated cells (The OD value of solvent control was set as 100\%) was assessed graphically from the corresponding concentration-response curves. The cytotoxicity assay of each compound was repeated three times. The mean $\mathrm{IC}_{50}$ value of three repeats was set as the result.

Differentiation of ES cells. As previously described, when undifferentiated $\mathrm{mES}$ cells are incubated in vitro 
Table I. Primer sequences used for reverse transcription-quantitative polymerase chain reaction.

\begin{tabular}{llc}
\hline Gene name & Forward primer sequence & Reverse primer sequence \\
\hline$\alpha / \beta-\mathrm{MHC}$ & CTTGTTGACCTGGGACTCGG & ACCTGTCCAAGTTCCGCAAG \\
GAPDH & GCCTTCTCCATGGTGGTGAA & GCACAGTCAAGGCCGAGAAT
\end{tabular}

MHC, myosin heavy chain.

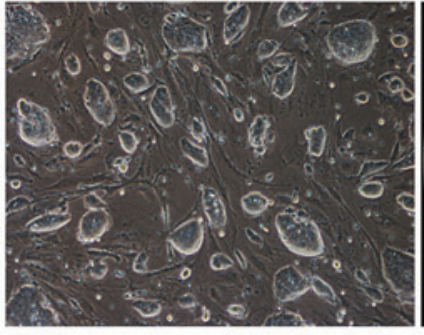

Undifferentiated mES cells

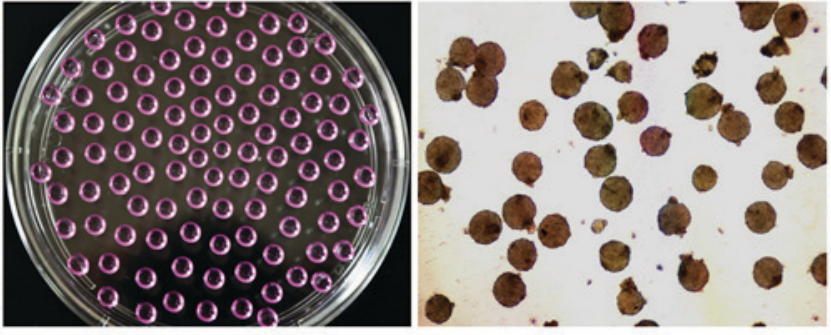

Hanging drops
Suspended EBs

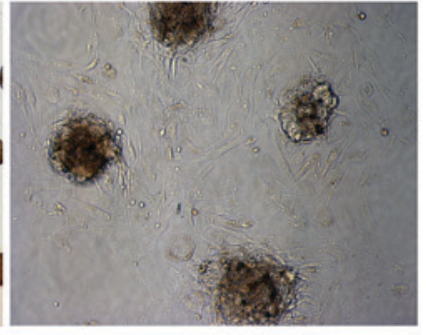

Differentiated attached cells

Figure 1. Protocols for mES cell differentiation. Undifferentiated mES cells were cultured using the hanging drop-suspension-adherence method to form EBs. mES, murine embryonic stem cells; EBs, embryoid bodies.

by the hanging drop-suspension-adherence method in ES medium without LIF, the cells can combine to form EBs (Fig. 1) $(2,9,15)$. In brief, $\sim 1,000 \mathrm{mES}$ cells in $20 \mu \mathrm{l}$ droplets of cell suspension were placed onto the inner side of the lid of a $10 \mathrm{~cm}$ Petri dish (BD Biosciences, Franklin Lakes, NJ, USA) filled with $5 \mathrm{ml} \mathrm{PBS}$ and then incubated at $37^{\circ} \mathrm{C}$ in $5 \%$ $\mathrm{CO}_{2}$ atmosphere. This 'hanging drop' culture was maintained in the absence of LIF to form EBs. Following culturing for 3 days, these EBs were transferred into sterile Petri dishes and cultured in suspension in $5 \mathrm{ml}$ differentiation medium for 2 days. Subsequently, these EBs were seeded on $0.1 \%$ gelatin-coated 6-well plates at a density of 100 EBs per well and incubated for an additional 5 days for differentiation into beating cardiomyocytes. mES cells were exposed to the test compound in appropriate concentrations from day 0 onwards over the complete culture duration as described. In Phase I, five concentrations were set for 5-fluorouracil $(0.02,0.04$, $0.06,0.08$ and $0.1 \mu \mathrm{g} / \mathrm{ml})$ and penicillin $\mathrm{G}(200,400,600$, 800 and $1,000 \mu \mathrm{g} / \mathrm{ml}$ ). In phase II, 5-fluorouracil served as positive control, and the appropriate concentration was set as $0.037 \mu \mathrm{g} / \mathrm{ml}$. In addition, five concentrations were set for eugenol and carnosic acid (2, 4, 6, 8 and $10 \mu \mathrm{g} / \mathrm{ml})$, as well as for procyanidin and dioctyl phthalate $(20,40,60,80$ and $100 \mu \mathrm{g} / \mathrm{ml}$ ). The setting of the concentrations of each test compound for differentiation assay was based on the results of the cytotoxicity assay and preliminary experiments. Untreated controls and the corresponding solvent controls were included in each experiment.

RNA isolation and reverse transcription-polymerase chain reaction $(R T-P C R)$ analysis. On day 10, 100 EBs per sample were harvested, and total RNA was isolated with TRIzol reagent (15596-026; Invitrogen; Thermo Fisher Scientific, Inc.). cDNA was synthesized from 1,000 ng RNA per reaction with the Revert Aid First Strand cDNA Synthesis kit (K1622;
Thermo Fisher Scientific, Inc.). The $\alpha / \beta-M H C$ gene expressed specially in cardiomyocyte differentiation was chosen as a marker gene, and GAPDH was chosen as the housekeeping gene. The polymerase chain reaction was performed in a T100 Thermal Cycler (Bio-Rad Laboratories, Inc., Hercules, CA, USA) with specific primers (Table I) by initial denaturation at $94^{\circ} \mathrm{C}$ for $3 \mathrm{~min}$, followed by 32 cycles of PCR amplification: Denaturation at $94^{\circ} \mathrm{C}$ for $30 \mathrm{sec}$, annealing at $62^{\circ} \mathrm{C}$ $(\alpha / \beta-\mathrm{MHC})$ or $56^{\circ} \mathrm{C}(\mathrm{GAPDH})$ for $30 \mathrm{sec}$, and completed by a final extension of $72^{\circ} \mathrm{C}$ for $5 \mathrm{~min}$ (16). PCR fragments were run on a $3 \%$ agarose gel containing $0.2 \mu \mathrm{g} / \mathrm{ml}$ ethidium bromide (Sangon Biotech Co., Ltd., Shanghai, China), visualized under UV light with a Molecular Imager ChemiDoc XRS system (Bio-Rad Laboratories, Inc.) and analyzed with Quantity One 1-D analysis software version, 4.6.2 (Bio-Rad Laboratories, Inc.) (39). The ID $_{50}$ of the test compound, expressed as the concentration that suppressed the expression of MHC by $50 \%$ in comparison with control, was calculated from a concentration-response curve. The differentiation assay of each compound was repeated three times. The mean $\mathrm{ID}_{50}$ value of three times was set as the result.

Classification of the embryotoxicity. The embryotoxic potential of each test compound was classified into three grades (strong, weak and non-embryotoxic) based on three values $\left(\mathrm{IC}_{50} 3 \mathrm{~T} 3, \mathrm{IC}_{50} \mathrm{ES}\right.$ and $\left.\mathrm{ID}_{50}\right)$, according to the PM proposed by ECVAM $(2,19)$. The values were as follows: I, $5.9157 \mathrm{lg}\left(\mathrm{IC}_{50} 3 \mathrm{~T} 3\right)+3.500 \mathrm{lg}$ $\left(\mathrm{IC}_{50} \mathrm{ES}\right)-5.307$ [( $\left.\left.\mathrm{IC}_{50} 3 \mathrm{~T} 3-\mathrm{ID}_{50} \mathrm{D} 3\right) / \mathrm{IC}_{50} 3 \mathrm{~T} 3\right]-15.72 ; \mathrm{II}$, $3.651 \mathrm{lg}\left(\mathrm{IC}_{50} 3 \mathrm{~T} 3\right)+2.394 \mathrm{lg}\left(\mathrm{IC}_{50} \mathrm{ES}\right)-2.033\left[\left(\mathrm{IC}_{50} 3 \mathrm{~T} 3-\right.\right.$ $\left.\left.\mathrm{ID}_{50} \mathrm{D} 3\right) / \mathrm{IC}_{50} 3 \mathrm{~T} 3\right]-6.8$; and III, $-0.125 \mathrm{lg}\left(\mathrm{IC}_{50} 3 \mathrm{~T} 3\right)+1.917 \mathrm{lg}$ $\left(\mathrm{IC}_{50} \mathrm{ES}\right)+1.500\left[\left(\mathrm{IC}_{50} 3 \mathrm{~T} 3-\mathrm{ID}_{50} \mathrm{D} 3\right) / \mathrm{IC}_{50} 3 \mathrm{~T} 3\right]-2.67$. The grades were classified as follows: Class 1 , non-embryotoxicity, If I $>$ II and I>III; Class 2, weak embryotoxicity, If II $>$ I and II $>$ III; and Class 3, strong embryotoxicity, If III $>$ I and III $>$ II. 
A

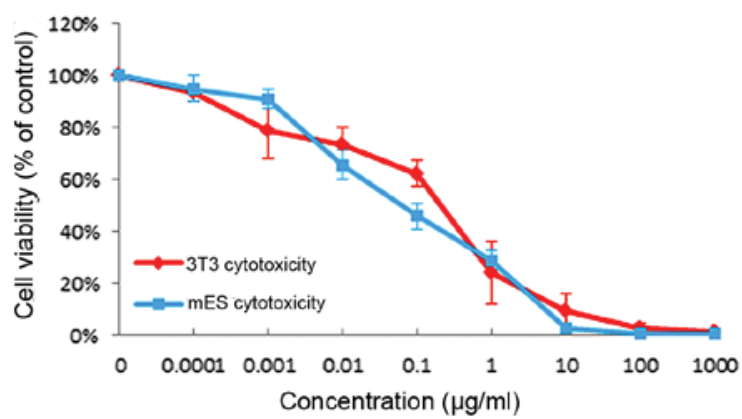

C

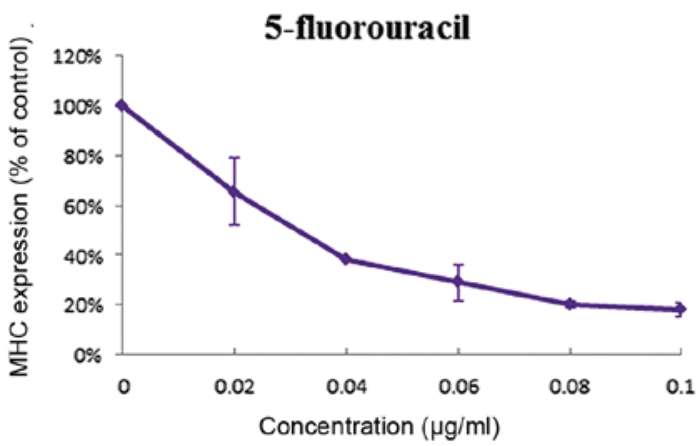

B

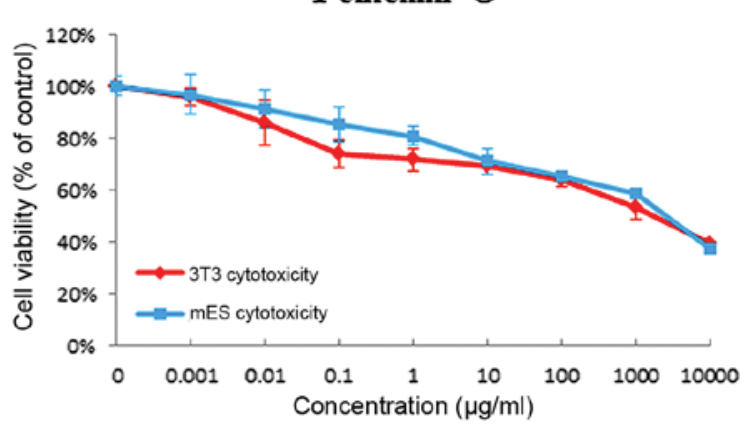

D

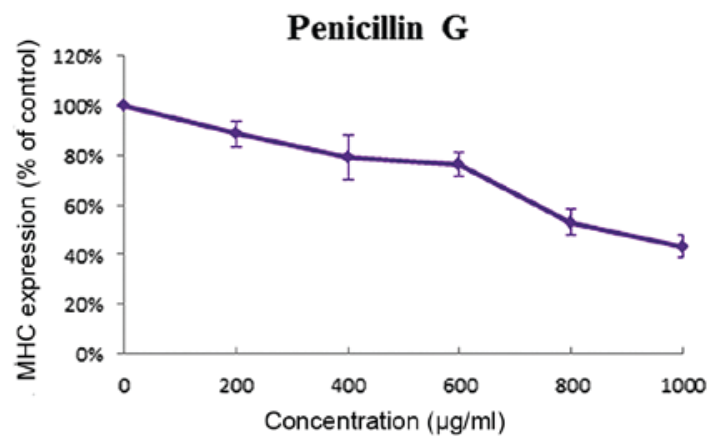

Figure 2. Concentration-response curves of the test compounds: 5-fluorouracil and penicillin G. There were three endpoints of the EST: (A and B) Cytotoxicity of mES-D3 and 3T3 cells and (C and D) inhibition of differentiation of mES-D3 cells were measured for selected concentrations and normalized to control. Inhibition of differentiation was demonstrated by measuring MHC gene expression, as it is a marker of cardiac development during ES cell differentiation. Data are presented as the mean \pm standard error of the mean $(n=3)$. mES, murine embryonic stem cells; 3T3, BALB/c 3T3 cells; EST, embryonic stem cell test; MHC, myosin heavy chain.
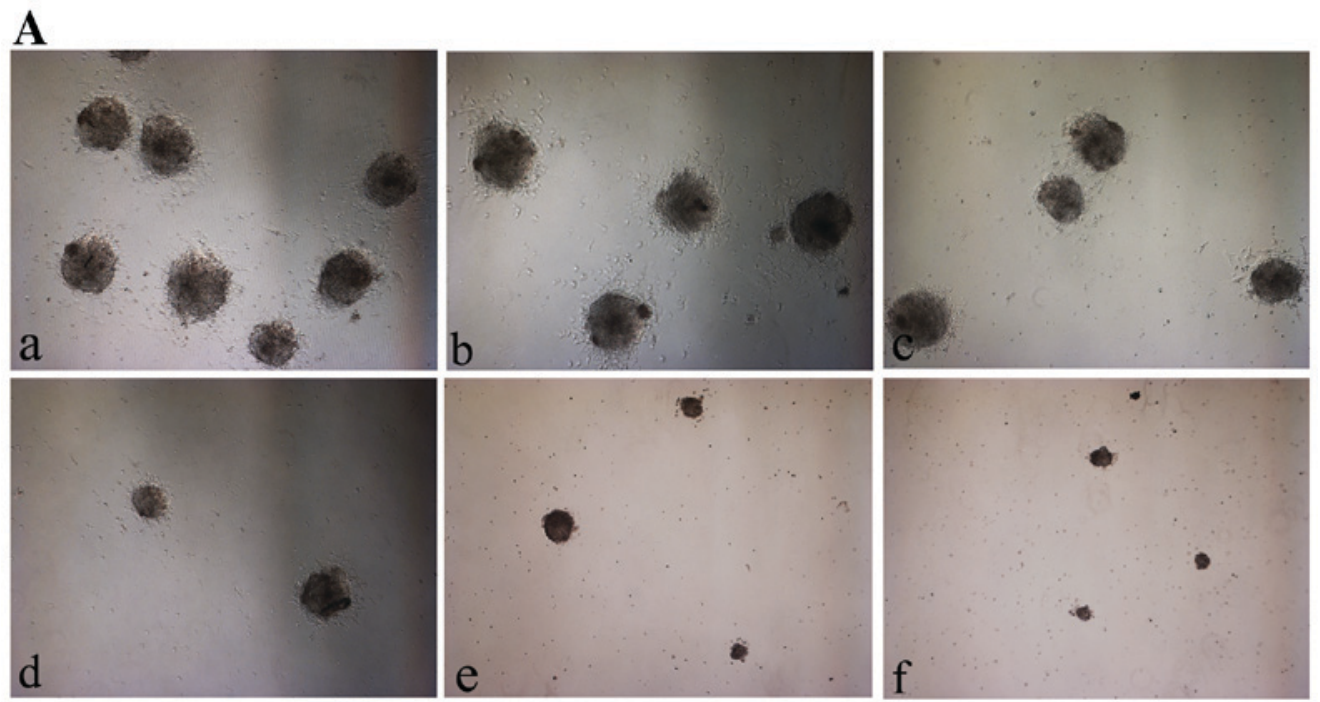

\section{B}

5-Fluorouracil

C

Penicillin G
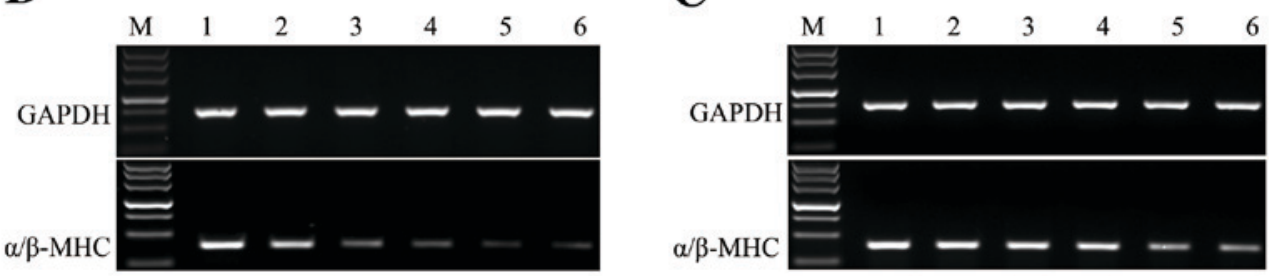

Figure 3. (A) In the differentiation assay, 5-fluorouracil exhibited inhibition for mES cells differentiated into cardiomyoctyes in a dose-dependent manner. a, Solvent control; b, $0.02 \mu \mathrm{g} / \mathrm{ml} ; \mathrm{c}, 0.04 \mu \mathrm{g} / \mathrm{ml} ; \mathrm{d}, 0.06 \mu \mathrm{g} / \mathrm{ml} ; \mathrm{e}, 0.08 \mu \mathrm{g} / \mathrm{ml} ; \mathrm{f}, 0.1 \mu \mathrm{g} / \mathrm{ml}$. Images were captured at x 40 magnification. (B and C) Expression levels of the $\alpha / \beta-\mathrm{MHC}$ in mES cells treated by different concentrations of test compounds were analyzed by reverse transcription quantitative-polymerase chain reaction, normalized to GAPDH. (B) 5-fluorouracil electrophoresis. M, DL500 DNA Marker (500, 400, 300, 200, 150, 100, 50 bp); 1, Solvent control; 2, $0.02 \mu \mathrm{g} / \mathrm{ml} ; 3,0.04 \mu \mathrm{g} / \mathrm{ml} ; 4,0.06 \mu \mathrm{g} / \mathrm{ml} ; 5,0.08 \mu \mathrm{g} / \mathrm{ml} ; 6,0.1 \mu \mathrm{g} / \mathrm{ml}$. (C) Penicillin G electrophoresis, M, DL500 DNA Marker; 1, Solvent control; 2, $200 \mu \mathrm{g} / \mathrm{ml} ; 3,400 \mu \mathrm{g} / \mathrm{ml} ; 4,600 \mu \mathrm{g} / \mathrm{ml} ; 5,800 \mu \mathrm{g} / \mathrm{ml} ; 6,1,000 \mu \mathrm{g} / \mathrm{ml}$. mES, murine embryonic stem cells; MHC, myosin heavy chain. 
Statistical analysis. The statistical analysis was performed using SPSS software (version, 19.0; IBM SPSS, Armonk, NY, USA) Data were expressed as mean \pm standard error of the mean. Each data point represented the mean from three independent experiments. $\mathrm{P}<0.05$ was considered to indicate a statistically significant difference.

\section{Results}

Phase I: Evaluation of the feasibility of the established EST model with control substances. The strongly embryotoxic 5-fluorouracil was used as a positive control and the non-embryotoxic penicillin $\mathrm{G}$ was used as a negative control; 5-fluorouracil and penicillin $\mathrm{G}$ are the classic positive and negative substances routinely used to evaluate the feasibility of the established EST model $(2,5,6,20)$. In the present study, 5-fluorouracil exhibited strong embryotoxicity. When treated with 5-fluorouracil, the viability of 3T3 cells and mES cells decreased dose-dependently (Fig. 2A) and were influenced at very low concentrations $\left(\mathrm{IC}_{50} 3 \mathrm{~T} 3,0.244 \pm 0.051 \mu \mathrm{g} / \mathrm{ml} ; \mathrm{IC}_{50} \mathrm{ES}\right.$, $0.080 \pm 0.016 \mu \mathrm{g} / \mathrm{ml}$ ). In the differentiation assay (Figs. $2 \mathrm{C}$, $3 \mathrm{~A}$ and $\mathrm{B}), 5$-fluorouracil exhibited strong inhibition of the differentiation of ES cells into contracting cardiomyoctyes $\left(\mathrm{ID}_{50}, 0.037 \pm 0.006 \mu \mathrm{g} / \mathrm{ml}\right.$ ) as indicated by the expression of marker gene $(\alpha / \beta-\mathrm{MHC})$ analyzed by RT-PCR. Test results demonstrated that penicillin $\mathrm{G}$ exhibited little cytotoxicity to $3 \mathrm{~T} 3$ cells or $\mathrm{mES}$ cells $\left(\mathrm{IC}_{50} 3 \mathrm{~T} 3,1,160.667 \pm 69.07 \mu \mathrm{g} / \mathrm{ml}\right.$; $\mathrm{IC}_{50} \mathrm{ES}, 1,567.497 \pm 152.471 \mu \mathrm{g} / \mathrm{ml}$; Fig. 2B) and weak inhibition of ES cells differentiation into contracting cardiomyoctyes $\left(\mathrm{ID}_{50}, 980.098 \pm 24.693 \mu \mathrm{g} / \mathrm{ml}\right.$; Figs. 2D and 3C). Even at the highest concentration tested $(1,000 \mu \mathrm{g} / \mathrm{ml})$, only a minor inhibition was observed. According to the PM, 5-fluorouracil and penicillin $\mathrm{G}$ were classified as reagents with strong embryotoxicity and non-embryotoxicity, respectively. The embryotoxicity classifications were the same as those in the ECVAM validation study.

Phase II: Embryotoxicity assessment of four compounds with the model of EST. In order to expand the application of EST, the embryotoxic potentials of four selected compounds (eugenol, carnosic acid, procyanidin and dioctyl phthalate) were assessed with the model in phase II.

Eugenol. Test results demonstrated that eugenol presented strong embryotoxicity in the EST. Both 3T3 cells and mES cells were markedly sensitive to the cytotoxic effect of eugenol $\left(\mathrm{IC}_{50} 3 \mathrm{~T} 3,9.441 \pm 2.849 \mu \mathrm{g} / \mathrm{ml} ; \mathrm{IC}_{50} \mathrm{ES}, 1.929 \pm 0.329 \mu \mathrm{g} / \mathrm{ml}\right.$; Fig. 4A). In the differentiation assay (Figs. 4E and 5A), when the EBs were exposed to eugenol, a concentration-dependent inhibition of differentiation was observed. Treatment with eugenol resulted in the direct inhibition of differentiation of mES-D3 cells at very low concentrations $\left(\operatorname{ID}_{50}, 5.434 \pm 0.715 \mu \mathrm{g} / \mathrm{ml}\right)$.

Carnosic acid. In the cytotoxicity assay, the test results indicated that carnosic acid exhibited greater cytotoxicity effects on mES cells than on 3T3 cells $\left(\mathrm{IC}_{50} 3 \mathrm{~T} 3,26.28 \pm 3.861 \mu \mathrm{g} / \mathrm{ml}\right.$; $\mathrm{IC}_{50} \mathrm{ES}, 5.771 \pm 1.297 \mu \mathrm{g} / \mathrm{ml}$; Fig. 4B). Exposure of the EBs to carnosic acid, inhibition of differentiation into cardiomyocytes was detected at similar concentrations as the $\mathrm{IC}_{50}$ test in $\mathrm{ES}$ cells (Figs. 4F and 5B) and the ID $_{50}$ was $6.143 \pm 0.575 \mu \mathrm{g} / \mathrm{ml}$.
Procyanidin. As presented in Fig. 4C, 3 T3 cells were notably sensitive to thecytotoxiceffectof procyanidinincomparisontomES cells $\left(\mathrm{IC}_{50} 3 \mathrm{~T} 3,12.1 \pm 1.828 \mu \mathrm{g} / \mathrm{ml} ; \mathrm{IC}_{50} \mathrm{ES}, 145.139 \pm 21.121 \mu \mathrm{g} / \mathrm{ml}\right)$ in the cytotoxicity assay. The differentiation assay demonstrated that procyanidin had weak inhibition of ES cell differentiation $\left(\mathrm{ID}_{50}, 72.493 \pm 2.706 \mu \mathrm{g} / \mathrm{ml}\right.$; Figs. $4 \mathrm{G}$ and $\left.5 \mathrm{C}\right)$.

Dioctyl phthalate. In the EST, when the cells were treated with dioctyl phthalate, greater cytotoxicity effects were identified on mES cells than on 3T3 cells ( $\mathrm{IC}_{50} 3 \mathrm{~T} 3$, $213.487 \pm 28.158 \mu \mathrm{g} / \mathrm{ml} ; \mathrm{IC}_{50}$ ES, $123.587 \pm 24.944 \mu \mathrm{g} / \mathrm{ml}$; Fig. 4D). Under dioctyl phthalate treatment, the authors demonstrated that it could inhibit the differentiation of $\mathrm{mES}$ cells at relatively low concentrations $\left(\mathrm{ID}_{50}, 60.116 \pm 5.39 \mu \mathrm{g} / \mathrm{ml}\right.$; Figs. 4H and 5D).

Subsequently, the mean values of $\mathrm{IC}_{50} 3 \mathrm{~T} 3, \mathrm{IC}_{50} \mathrm{ES}$ and $\mathrm{ID}_{50}$ of each compound were substituted into the PM, and the embryotoxic potentials of each compound were successfully classified: Eugenol displayed strong embryotoxicity, carnosic acid and dioctyl phthalate displayed weak embryotoxicity, while procyanidin displayed non-embryotoxicity. Summary results are presented in Table II.

\section{Discussion}

In the early $1960 \mathrm{~s},>10,000$ infants were born with phocomelia (malformation of the limbs) due to exposure to thalidomide throughout the world (40). The negative effects of thalidomide have focused worldwide attention squarely on the embryotoxicity caused by environmental insults (e.g., drugs, diet and environmental toxic chemicals). At present, a wide range of compounds needs to be tested, and, in particular, the development of those compounds that may be used in pregnant women (those with low toxic potency) must be prioritized. Currently, embryotoxicity is mainly detected by in vivo tests. However, in vivo detection requires a large number of experimental animals and generous amounts of test chemical with long duration, which altogether make the studies extremely costly $(41,42)$. The EST is currently the only test method that is completely free from use of animals. The validation study of EST funded by ECVAM, presented a good overall test accuracy of $78 \%$ for classification of the 20 tested chemicals with known in vivo embryotoxic potential (43). In particular, the predictability of $100 \%$ for strongly embryotoxic chemicals was obtained, and the precision was considered to be fairly $\operatorname{good}(2,3,43)$.

In the present study, a model of EST was established according to the standard EST system of ECVAM, and the validity of the model was verified with 5-fluorouracil as a positive control and penicillin $\mathrm{G}$ as a negative control. During pregnancy, the developing embryo is very sensitive, and a variety of compounds have been reported to be toxic or teratogenic for its development $(44,45)$. Eugenol, carnosic acid, procyanidin and dioctyl phthalate, commonly-used compounds, have already been used food, cosmetic and medical applications, within a specific range of concentrations. However, little is known about their influence on embryo development. To the best of the authors' knowledge, there are no available studies describing the effect of these compounds on the embryotoxicity in vitro. For this reason, subsequently, 

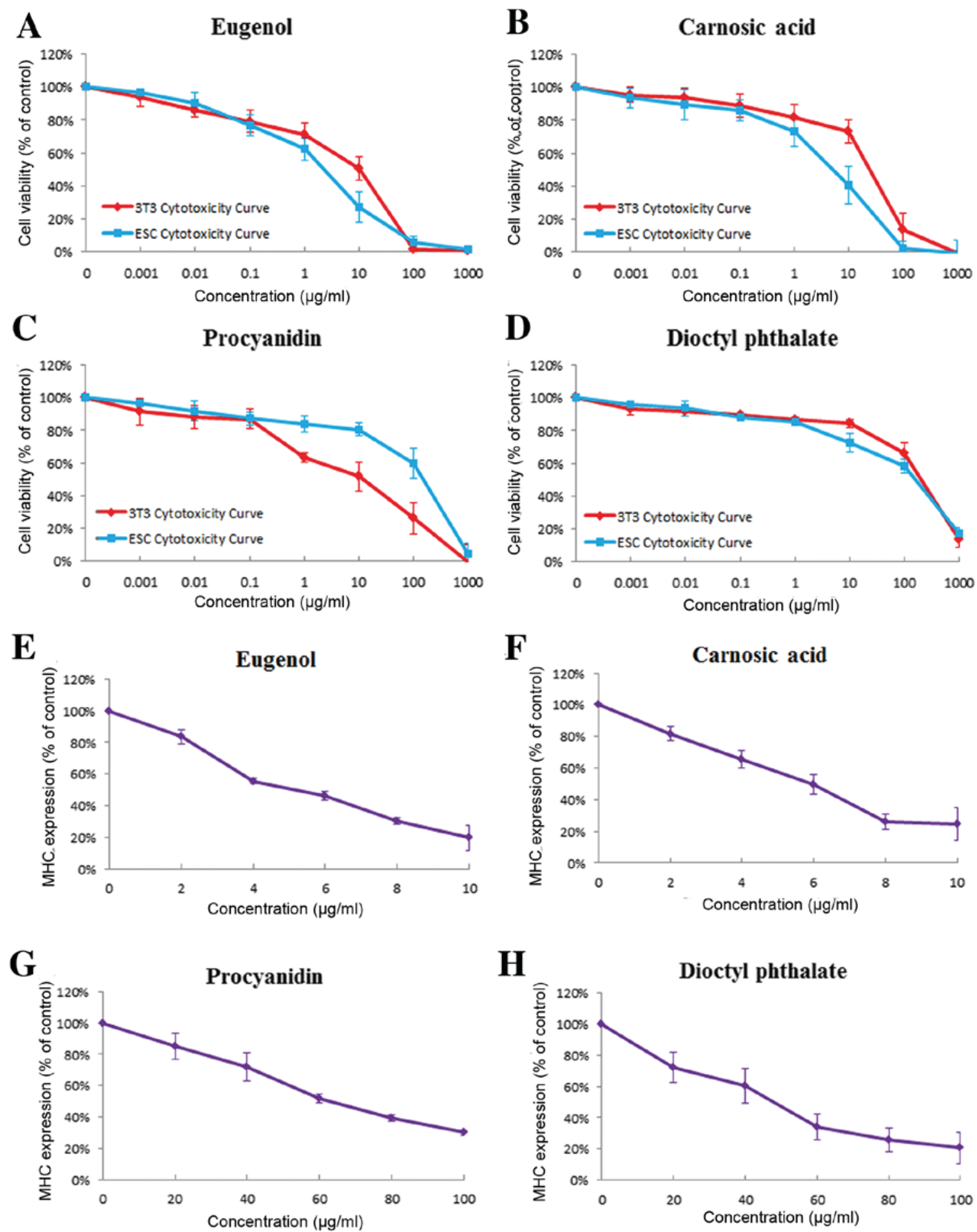

Figure 4. Concentration-response curves of test compounds (eugenol, carnosic acid, procyanidin and dioctyl phthalate). The three endpoints of the EST were tested: (A-D) Cytotoxicity of mES and $3 \mathrm{~T} 3$ cells and (E-H) inhibition of differentiation of mES cells were measured for selected concentrations and normalized to the control. Data are presented as the mean \pm standard error of the mean $(n=3)$. EST, embryonic stem cell test; mES, murine embryonic stem cells; 3T3, BALB/c 3T3 cells; MHC, myosin heavy chain.

the present study assessed the embryotoxicity of these four compounds with the established EST model.

Domaracky et al (46) studied the influence of eugenol on the development of mouse preimplantation embryos in vivo. The study indicated that eugenol may induce a significantly increased rate of cell death and affect the development of embryo. For its isomer, isoeugenol, when received by pregnant rats (at the highest dose of $1,000 \mathrm{mg} / \mathrm{kg} /$ day), it caused intrauterine growth retardation and skeletal defects in fetuses (47). The current results indicated that $3 \mathrm{~T} 3$ cells and mES cells were both sensitive to eugenol. A higher incidence of cell death was observed following treatment with eugenol. According to the test data, eugenol was classified as strongly embryotoxic. Research on carnosic acid has demonstrated that a short-term 
Table II. Summary of mean $\mathrm{IC}_{50} 3 \mathrm{~T} 3, \mathrm{IC}_{50} \mathrm{ES}$ and $\mathrm{ID}_{50}$ values obtained in three independent experiments and classification of test compounds according to the prediction model. Data are presented as $\mathrm{IC}_{50}$ and $\mathrm{ID}_{50}$ values $(\mu \mathrm{g} / \mathrm{ml}) \pm$ standard error of the mean, and embryotoxicity was classified as strong, weak or non-embryotoxic.

\begin{tabular}{lcccc}
\hline Tested compound & $\mathrm{IC}_{50} 3 \mathrm{~T} 3(\mu \mathrm{g} / \mathrm{ml})$ & $\mathrm{IC}_{50} \mathrm{ES}(\mu \mathrm{g} / \mathrm{ml})$ & $\mathrm{ID}_{50}(\mu \mathrm{g} / \mathrm{ml})$ & Classification of the embryotoxicity \\
\hline 5-fluorouracil & $0.244 \pm 0.051$ & $0.080 \pm 0.016$ & $0.037 \pm 0.006$ & Strong \\
Penicillin G & $1160.667 \pm 69.070$ & $1567.497 \pm 152.471$ & $980.098 \pm 24.693$ & None \\
Eugenol & $9.441 \pm 2.849$ & $1.929 \pm 0.329$ & $5.434 \pm 0.715$ & Strong \\
Carnosic acid & $26.280 \pm 3.861$ & $5.771 \pm 1.297$ & $6.143 \pm 0.575$ & Weak \\
Procyanidin & $12.100 \pm 1.828$ & $145.139 \pm 21.121$ & $72.493 \pm 2.706$ & None \\
Dioctyl phthalate & $213.487 \pm 28.158$ & $123.587 \pm 24.944$ & $60.116 \pm 5.390$ & Weak \\
\hline
\end{tabular}

3T3, BALB/c-3T3 cells; ES, murine embryonic stem cells.

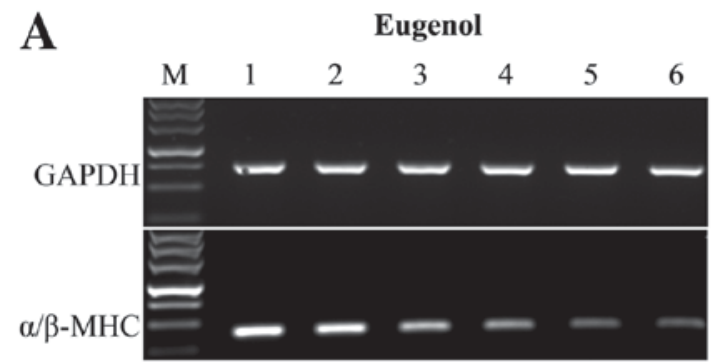

B
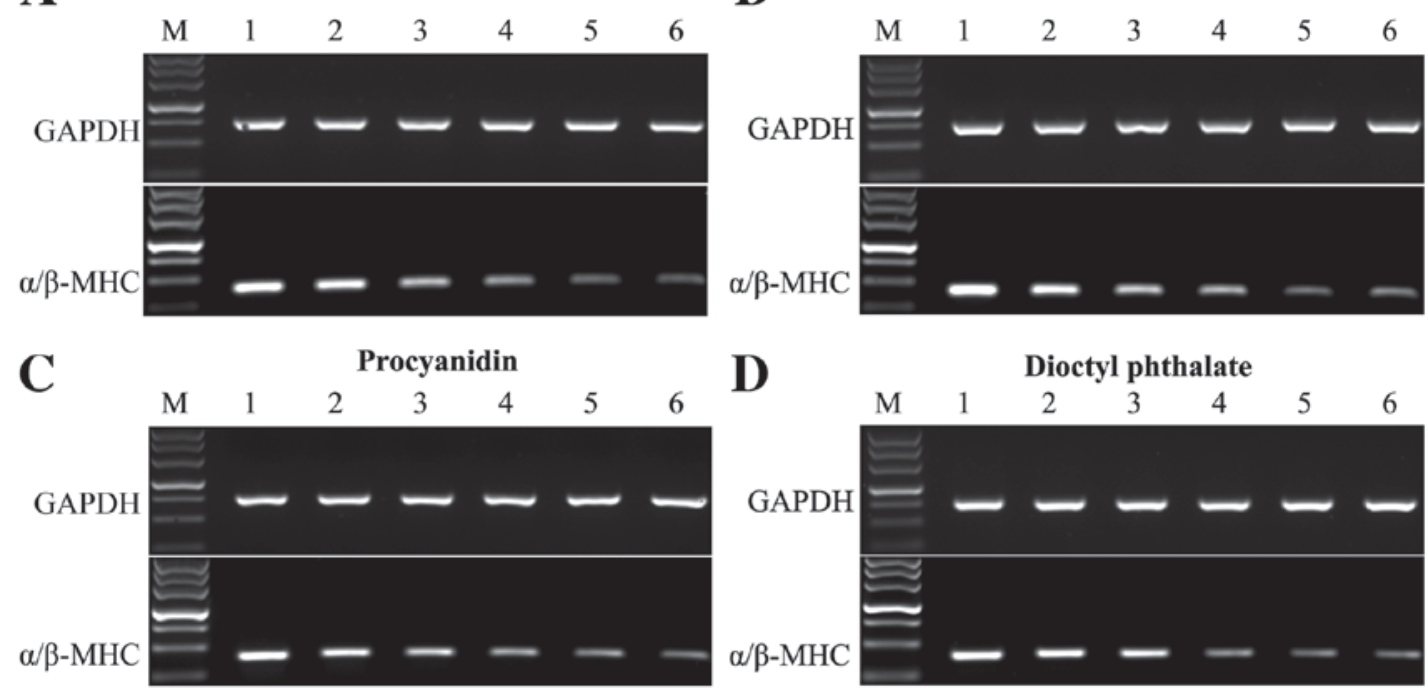

Figure 5. Expression levels of the $\alpha / \beta$-MHC at different concentrations of test compounds were analyzed by reverse transcription quantitative-polymerase chain reaction, normalized to GAPDH expression. (A and B): Eugenol, carnosic acid. M, DL500 DNA Marker; 1 , Solvent control; $2,2 \mu \mathrm{g} / \mathrm{ml} ; 3,4 \mu \mathrm{g} / \mathrm{ml}$; 4, $6 \mu \mathrm{g} / \mathrm{ml} ; 5,8 \mu \mathrm{g} / \mathrm{ml} ; 6,10 \mu \mathrm{g} / \mathrm{ml}$. (C and D): Procyanidin, dioctyl phthalate. M, DL500 DNA Marker; 1, Solvent control; 2, $20 \mu \mathrm{g} / \mathrm{ml} ; 3,40 \mu \mathrm{g} / \mathrm{ml} ; 4,60 \mu \mathrm{g} / \mathrm{ml} ;$ $5,80 \mu \mathrm{g} / \mathrm{ml} ; 6,100 \mu \mathrm{g} / \mathrm{ml}$. MHC, myosin heavy chain.

oral administration has a relatively low toxicity profile, and the oral lethal dose for mice was $7,100 \mathrm{mg} / \mathrm{kg}$ of body weight (48). The present study suggested that carnosic acid was weakly embryotoxic. Therefore, for the use of carnosic acid, pregnant women must be cautious. However, toxicological studies have indicated that procyanidin is nontoxic and does not cause any detrimental effects in vivo $(49,50)$. According to these results, procyanidin is safe and non-embryotoxic under the conditions investigated in the present study. With regards to dioctyl phthalate, many studies on animals clearly demonstrated that dioctyl phthalate could cause a certain tissue/organ toxicity (51-54), developmental toxicity (55-58) and reproductive toxicity $(37,59-61)$ in some species, such as rats, mice and marmosets $(36,62,63)$. To the best of the authors' knowledge, there are no data on the embryotoxicity of dioctyl phthalate obtained by in vitro animal-free tests. The present study employed the established EST to predict the embryotoxicity of dioctyl phthalate in vitro, and the results indicated that dioctyl phthalate exhibited weak embryotoxicity.
Taken together, the authors successfully established the model of EST, and further assessed embryotoxicity of four selected compounds with this model. In the future, it will be important to determine the embryotoxicity of the many commonly used compounds. The EST system for embryotoxicity screening test is rapid, simple and sensitive. It may be used for high-throughput screening of embryotoxicity of test substance.

\section{Acknowledgments}

This work was supported by the National Natural Science Foundation of China (grant nos. 30871246, 81070993, 81272972 and 81472355), the National Basic Research Program of China (grant no. 2010CB833605), the Specialized Research Fund for the Doctoral Program of Higher Education of China (grant no. 20120162110059), the Foundation of Hunan Provincial Science and Technology Department (grant nos. 2010TD2026 and 2011FJ4180), the Program 
for New Century Excellent Talents in University (grant no. NCET-10-0790), the Key Program of Central South University (grant no. 2010QYZD006) and the Open-End Fund for the Valuable and Precision Instruments of Central South University (grant nos. CSUZC201634 and CSUZC201638).

\section{References}

1. Scholz G, Genschow E, Pohl I, Bremer S, Paparella M, Raabe H, Southee J and Spielmann H: Prevalidation of the embryonic stem cell test (EST)-A new in vitro embryotoxicity Test. Toxicol In Vitro 13: 675-681, 1999.

2. Genschow E, Spielmann H, Scholz G, Pohl I, Seiler A, Clemann N, Bremer S and Becker K: Validation of the embryonic stem cell test in the international ECVAM validation study on three in vitro embryotoxicity tests. Altern Lab Anim 32: 209-244, 2004.

3. Seiler AE and Spielmann H: The validated embryonic stem cell test to predict embryotoxicity in vitro. Nat Protoc 6: 961-978, 2011

4. Chen R, Chen J, Cheng S, Qin J, Li W, Zhang L, Jiao H, Yu X, Zhang X, Lahn BT and Xiang AP: Assessment of embryotoxicity of compounds in cosmetics by the embryonic stem cell test Toxicol Mech Methods 20: 112-118, 2010.

5. Festag M, Viertel B, Steinberg P and Sehner C: An in vitro embryotoxicity assay based on the disturbance of the differentiation of murine embryonic stem cells into endothelial cells. II Testing of compounds. Toxicol In Vitro 21: 1631-1640, 2007.

6. Li L, Zhang X, Wang L, Chai Z, Shen X, Zhang Z and Liu C: A toxicology study to evaluate the embryotoxicity of metformin compared with the hypoglycemic drugs, the anticancer drug, the anti-epileptic drug, the antibiotic, and the cyclo-oxygenase (COX)-2 inhibitor. J Diabetes 7: 839-849, 2015.

7. Paquette JA, Kumpf SW, Streck RD, Thomson JJ, Chapin RE and Stedman DB: Assessment of the embryonic stem cell test and application and use in the pharmaceutical industry. Birth Defects Res B Dev Reprod Toxicol 83: 104-111, 2008.

8. Chen F, Cao F, Su Z, Li L, Huang A and Xu H: Assessment of the developmental toxicity of epidermal growth factor using embryonic stem cell test. Trop J Pharm Res 13: 689, 2014

9. Fuegemann CJ, Samraj AK, Walsh S, Fleischmann BK, Jovinge S and Breitbach M: Differentiation of mouse embryonic stem cells into cardiomyocytes via the hanging-drop and mass culture methods. Curr Protoc Stem Cell Biol Chapter 1: Unit 1F 11, 2010.

10. Doetschman TC, Eistetter H, Katz M, Schmidt W and Kemler R: The in vitro development of blastocyst-derived embryonic stem cell lines: Formation of visceral yolk sac, blood islands and myocardium. J Embryol Exp Morphol 87: 27-45, 1985.

11. Sánchez A, Jones WK, Gulick J, Doetschman T and Robbins J: Myosin heavy chain gene expression in mouse embryoid bodies. An in vitro developmental study. J Biol Chem 266: 22419-22426, 1991.

12. Robbins J, Gulick J, Sanchez A, Howles P and Doetschman T: Mouse embryonic stem cells express the cardiac myosin heavy chain genes during development in vitro. J Biol Chem 265: 11905-11909, 1990.

13. de Jong E, Louisse J, Verwei M, Blaauboer BJ, van de Sandt JJ, Woutersen RA, Rietjens IM and Piersma AH: Relative developmental toxicity of glycol ether alkoxy acid metabolites in the embryonic stem cell test as compared with the in vivo potency of their parent compounds. Toxicol Sci 110: 117-124, 2009.

14. Deng SQ, Xu H, He Q, Jiang HX, Su BJ and Zhang QH: Detecting the developmental toxicity of bFGF in the embryonic stem cell test using differential gene expression of differentiation-related genes. Toxicol Mech Methods 24: 323-331, 2014.

15. Schulpen SH, Pennings JL, Tonk EC and Piersma AH: A statistical approach towards the derivation of predictive gene sets for potency ranking of chemicals in the mouse embryonic stem cell test. Toxicol Lett 225: 342-349, 2014.

16. zur Nieden NI, Ruf LJ, Kempka G, Hildebrand H and Ahr HJ: Molecular markers in embryonic stem cells. Toxicol In Vitro 15: 455-461, 2001.

17. Nieden NI, Kempka G and Ahr HJ: Molecular multiple endpoint embryonic stem cell test-a possible approach to test for the teratogenic potential of compounds. Toxicol Appl Pharmacol 194: 257-269, 2004

18. Seiler A, Visan A, Buesen R, Genschow E and Spielmann H: Improvement of an in vitro stem cell assay for developmental toxicity: The use of molecular endpoints in the embryonic stem cell test. Reprod Toxicol 18: 231-240, 2004.
19. Genschow E, Scholz G, Brown N, Piersma A, Brady M, Clemann N, Huuskonen H, Paillard F, Bremer S, Becker K and Spielmann H: Development of prediction models for three in vitro embryotoxicity tests in an ECVAM validation study. In Vitr Mol Toxicol 13: 51-66, 2000.

20. Buesen R, Genschow E, Slawik B, Visan A, Spielmann H, Luch A and Seiler A: Embryonic stem cell test remastered: Comparison between the validated EST and the new molecular FACS-EST for assessing developmental toxicity in vitro. Toxicol Sci 108: 389-400, 2009.

21. Jadhav BK, Khandelwal KR, Ketkar AR and Pisal SS: Formulation and evaluation of mucoadhesive tablets containing eugenol for the treatment of periodontal diseases. Drug Dev Ind Pharm 30: 195-203, 2004

22. Chami N, Chami F, Bennis S, Trouillas J and Remmal A: Antifungal treatment with carvacrol and eugenol of oral candidiasis in immunosuppressed rats. Braz J Infect Dis 8: 217-226, 2004.

23. Dip EC, Pereira NA and Fernandes PD: Ability of eugenol to reduce tongue edema induced by Dieffenbachia picta Schott in mice. Toxicon 43: 729-735, 2004

24. Fischedick JT, Standiford M, Johnson DA and Johnson JA: Structure activity relationship of phenolic diterpenes from Salvia officinalis as activators of the nuclear factor E2-related factor 2 pathway. Bioorg Med Chem 21: 2618-2622, 2013.

25. Bai N, He K, Roller M, Lai CS, Shao X, Pan MH and Ho CT: Flavonoids and phenolic compounds from Rosmarinus officinalis. J Agric Food Chem 58: 5363-5367, 2010.

26. Yu YM, Lin $\mathrm{CH}$, Chan HC and Tsai HD: Carnosic acid reduces cytokine-induced adhesion molecules expression and monocyte adhesion to endothelial cells. Eur J Nutr 48: 101-106, 2009.

27. Mengoni ES, Vichera G, Rigano LA, Rodriguez-Puebla ML, Galliano SR, Cafferata EE, Pivetta OH, Moreno S and Vojnov AA: Suppression of COX-2, IL- $1 \beta$ and TNF- $\alpha$ expression and leukocyte infiltration in inflamed skin by bioactive compounds from Rosmarinus officinalis L. Fitoterapia 82: 414-421, 2011.

28. Xiang Q, Liu Z, Wang Y, Xiao H, Wu W, Xiao C and Liu X: Carnosic acid attenuates lipopolysaccharide-induced liver injury in rats via fortifying cellular antioxidant defense system. Food Chem Toxicol 53: 1-9, 2013.

29. Ibarra A, Cases J, Roller M, Chiralt-Boix A, Coussaert A and Ripoll C: Carnosic acid-rich rosemary (Rosmarinus officinalis $L$.)leaf extract limits weight gain and improves cholesterol levels and glycaemia in mice on a high-fat diet. Br J Nutr 106: 1182-1189, 2011.

30. Birtic S, Dussort P, Pierre FX, Bily AC and Roller M: Carnosic acid. Phytochemistry 115: 9-19, 2015.

31. Santos-Buelga $\mathrm{C}$ and Scalbert A: Proanthocyanidins and tannin-like compounds-nature, occurrence, dietary intake and effects on nutrition and health. J Sci Food Agriculture 80: 1094-1117, 2000.

32. Monagas M, Quintanilla-López JE, Gómez-Cordovés C, Bartolomé B and Lebrón-Aguilar R: MALDI-TOF MS analysis of plant proanthocyanidins. J Pharm Biomed Anal 51: 358-372, 2010.

33. Yamakoshi J, Saito M, Kataoka S and Kikuchi M: Safety evaluation of proanthocyanidin-rich extract from grape seeds. Food Chem Toxicol 40: 599-607, 2002.

34. Corder R, Mullen W, Khan NQ, Marks SC, Wood EG, Carrier MJ and Crozier A: Oenology: Red wine procyanidins and vascular health. Nature 444: 566, 2006

35. Benson R: Hazard to the developing male reproductive system from cumulative exposure to phthalate esters-dibutyl phthalate, diisobutyl phthalate, butylbenzyl phthalate, diethylhexyl phthalate, dipentyl phthalate, and diisononyl phthalate. Regul Toxicol Pharmacol 53: 90-101, 2009.

36. Kavlock R, Boekelheide K, Chapin R, Cunningham M, Faustman E, Foster P, Golub M, Henderson R, Hinberg I, Little R, et al: NTP center for the evaluation of risks to human reproduction: Phthalates expert panel report on the reproductive and developmental toxicity of di(2-ethylhexyl) phthalate. Reprod Toxicol 16: 529-653, 2002.

37. Helal MA: Celery oil modulates DEHP-induced reproductive toxicity in male rats. Reprod Biol 14: 182-189, 2014.

38. Latini G: Monitoring phthalate exposure in humans. Clin Chim Acta 361: 20-29, 2005.

39. Li G, Ren C, Shi J, Huang W, Liu H, Feng X, Liu W, Zhu B, Zhang $\mathrm{C}$, Wang L, et al: Identification, expression and subcellular localization of ESRG. Biochem Biophys Res Commun 435: 160-164, 2013. 
40. van Dartel DA and Piersma AH: The embryonic stem cell test combined with toxicogenomics as an alternative testing model for the assessment of developmental toxicity. Reprod Toxicol 32: 235-244, 2011

41. Hartung T: Toxicology for the twenty-first century. Nature 460 208-212, 2009

42. Rovida $\mathrm{C}$ and Hartung T: Re-evaluation of animal numbers and costs for in vivo tests to accomplish REACH legislation requirements for chemicals-a report by the transatlantic think tank for toxicology (t(4)). ALTEX 26: 187-208, 2009.

43. Genschow E, Spielmann H, Scholz G, Seiler A, Brown N Piersma A, Brady M, Clemann N, Huuskonen H, Paillard F, et al: The ECVAM international validation study on in vitro embryotoxicity tests: Results of the definitive phase and evaluation of prediction models. European centre for the validation of alternative methods. Altern Lab Anim 30: 151-176, 2002.

44. Peters AK, Steemans M, Hansen E, Mesens N, Verheyen GR and Vanparys P: Evaluation of the embryotoxic potency of compounds in a newly revised high throughput embryonic stem cell test. Toxicol Sci 105: 342-350, 2008.

45. Jones KL, Lacro RV, Johnson KA and Adams J: Pattern of malformations in the children of women treated with carbamazepine during pregnancy. N Engl J Med 320: 1661-1666, 1989.

46. Domaracky M, Rehák P, Juhás S and Koppel J: Effects of selected plant essential oils on the growth and development of mouse preimplantation embryos in vivo. Physiol Res 56: 97-104, 2007.

47. George JD, Price CJ, Marr MC, Myers CB and Jahnke GD: Evaluation of the developmental toxicity of isoeugenol in Sprague-Dawley (CD) rats. Toxicol Sci 60: 112-120, 2001.

48. Wang QL, Li H, Li XX, Cui CY, Wang R, Yu NX and Chen LX: Acute and 30-day oral toxicity studies of administered carnosic acid. Food Chem Toxicol 50: 4348-4355, 2012.

49. Ray S, Bagchi D, Lim PM, Bagchi M, Gross SM, Kothari SC Preuss HG and Stohs SJ: Acute and long-term safety evaluation of a novel IH636 grape seed proanthocyanidin extract. Res Commun Mol Pathol Pharmacol 109: 165-197, 2001.

50. Lluís L, Muñoz M, Nogués MR, Sánchez-Martos V, Romeu M, Giralt M, Valls J and Solà R: Toxicology evaluation of a procyanidin-rich extract from grape skins and seeds. Food Chem Toxicol 49: 1450-1454, 2011.

51. Hazelton WI: A subchronic (4-week) dietary oral toxicity study of di(2-ethylhexyl) phthalate in B6FC3F1 mice. 8D submission, microfische no. OTS0535433: Submited to US EPA, Office of Toxic Substances, prepared for Eastman Kodak Company. Washington, DC, 1992.

52. Poon R, Lecavalier P, Mueller R, Valli VE, Procter BG and Chu I: Subchronic oral toxicity of di-n-octyl phthalate and di(2-Ethylhexyl) phthalate in the rat. Food Chem Toxicol 35: 225-239, 1997.
53. David RM, Moore MR, Cifone MA, Finney DC and Guest D: Chronic peroxisome proliferation and hepatomegaly associated with the hepatocellular tumorigenesis of di(2-ethylhexyl) phthalate and the effects of recovery. Toxicol Sci 50: 195-205, 1999.

54. Li SG, Huang X, Zhang XW and Xu SH: Effects of diethylhexyl phthalate on lipid peroxidation and the life-span in Drosophila melanogaster. Zhonghua Yu Fang Yi Xue Za Zhi 39: 111-114, 2005 (In Chinese).

55. Tyl R, Jones-Price C, Marr MC and Kimmel CA: Teratological evaluation of diethylhexylphthalate (CAS no. 117-81-7) in CD-1 mice. National Center for Toxicological Research, 1984.

56. Tyl RW, Price CJ, Marr MC and Kimmel CA: Developmental toxicity evaluation of dietary di(2-ethylhexyl)phthalate in Fischer 344 rats and CD-1 mice. Fundam Appl Toxicol 10: 395-412, 1988.

57. Peters JM, Taubeneck MW, Keen CL and Gonzalez FJ: $\mathrm{Di}(2$-ethylhexyl) phthalate induces a functional zinc deficiency during pregnancy and teratogenesis that is independent of peroxisome proliferator-activated receptor-alpha. Teratology 56 : 311-316, 1997

58. Dobrzynska MM, Tyrkiel EJ, Derezińska E, Pachocki KA and Ludwicki JK: Two generation reproductive and developmental toxicity following subchronic exposure of pubescent male mice to di(2-ethylhexyl)phthalate. Ann Agric Environ Med 19: 31-37, 2012.

59. Erkekoglu P, Zeybek ND, Giray B, Asan E, Arnaud J and Hincal F: Reproductive toxicity of di(2-ethylhexyl) phthalate in selenium-supplemented and selenium-deficient rats. Drug Chem Toxicol 34: 379-389, 2011.

60. Zhang XF, Zhang LJ, Li L, Feng YN, Chen B, Ma JM, Huynh E, Shi QH,De Felici M and Shen W: Diethylhexyl phthalate exposure impairs follicular development and affects oocyte maturation in the mouse. Environ Mol Mutagen 54: 354-361, 2013.

61. Zhang XF, Zhang T, Han Z, Liu JC, Liu YP, Ma JY, Li L and Shen W: Transgenerational inheritance of ovarian development deficiency induced by maternal diethylhexyl phthalate exposure. Reprod Fertil Dev 27: 1213-1221, 2015.

62. Hauser R and Calafat AM: Phthalates and human health. Occup Environ Med 62: 806-818, 2005.

63. Swan SH: Environmental phthalate exposure in relation to reproductive outcomes and other health endpoints in humans. Environ Res 108: 177-184, 2008 . 